\title{
College and University Library Buildings, I929-1949
}

Dr. Muller is director of libraries, Southern Illinois University, and chairman, A.C.R.L. Committee on College and University Library Buildings.

$\mathrm{T}$ HE accompanying statistical table completes a series of three compilations of college and university library buildings which were derived from the returns of a questionnaire survey conducted in the fall of 1949. The first compilation covered buildings under construction, or in the contract-drawing stage, in $1950 ;^{1}$ the second one supplied data about buildings expected to be constructed during the next decade. ${ }^{2}$

The present final statistical instalment covers library buildings erected since the beginning of the depression through the prosperity period following World War II. The compilation, although comprehensive, is not 100 per cent complete since it includes only accredited institutions listed in American Colleges and Universities (A. J. Brumbaugh, ed. 5th ed. Washington, American Council on Education, 1948), plus a few nonaccredited ones that were on addressograph stencils used by the A.L.A. Headquarters, and only those that returned the questionnaires. ${ }^{3}$

The 146 library buildings are listed in

${ }^{1}$ Muller, Robert H. "Library Building Construction Among Colleges and Universities." College and Research Libraries, 11 :259-61, July 1950.

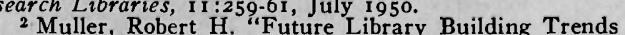
${ }^{2}$ Muller, Robert $\mathrm{H}$. "Future Library Building Trends
Among Colleges and Universities." College and Re. search Libraries, 1 2:33-36, January 1951.

3 Of the 820 accredited institutions listed in American Colleges and Universities, 430 returned questionnaires ( 52 per cent). Since the questionnaire emphasized aspects more pertinent to recent than to older buildings, it is reasonable to assume that most of the institutions failis reasonable to assume that most of the institutions fail-
ing to return questionnaires had relatively old library buildings. the order of estimated effective floor area for book storage and seats, from the largest (Columbia University) to the smallest (Hardin College). The floor area was estimated on the basis of volume capacity plus seats, assuming that on the average 15 active library volumes require one square foot of floor area, and one library seat requires 25 square feet.

The primary purpose of publishing the compilation is a practical one. It should enable the planners of new library buildings to locate buildings of similar size constructed in the past. It might be assumed that library building problems of institutions of similar size ane more alike than problems of institutions of widely varying sizes, everything else being equal. In a few instances where size is not considered of primary importance, it should not be too difficult to use the list for locating institutions of similar nature, such as technological schools, teachers' colleges, women's colleges, southern colleges, liberal arts colleges, universities of complex organization, etc., even though the buildings are not arranged according to such categories.

One of the most frequent type of request addressed to the A.C.R.L. Committee on College and University Library Buildings is for locations of library buildings that might be visited with profit or otherwise contacted by the librarian, architect, or president of an institution engaged in planning a new library building. Such requests seem to occur to planners as the natural first step in orienting themselves in 


\section{COLLEGE AND UNIVERSITY LIBRARY BUILDINGS CONSTRUCTED $1929-1949$}

(Arranged in the Order of Estimated Size)

\begin{tabular}{|c|c|c|c|c|c|c|}
\hline Name of Institution & $\begin{array}{l}\text { Year } \\
\text { Built }\end{array}$ & $\begin{array}{l}\text { Total } \\
\text { Volume } \\
\text { Capacity }\end{array}$ & $\begin{array}{c}\text { Building } \\
\text { now } \\
\text { Filled } \\
\text { (x for yes) }\end{array}$ & $\begin{array}{c}\text { Seats } \\
\text { plus Carrells } \\
\text { in Main } \\
\text { Library }\end{array}$ & $\begin{array}{l}\quad \text { Seats } \\
\text { Adequate } \\
\text { Ample } \\
\text { Insufficient }\end{array}$ & $\begin{array}{l}\text { (Ad) } \\
(\text { Am) } \\
\text { (In) }\end{array}$ \\
\hline 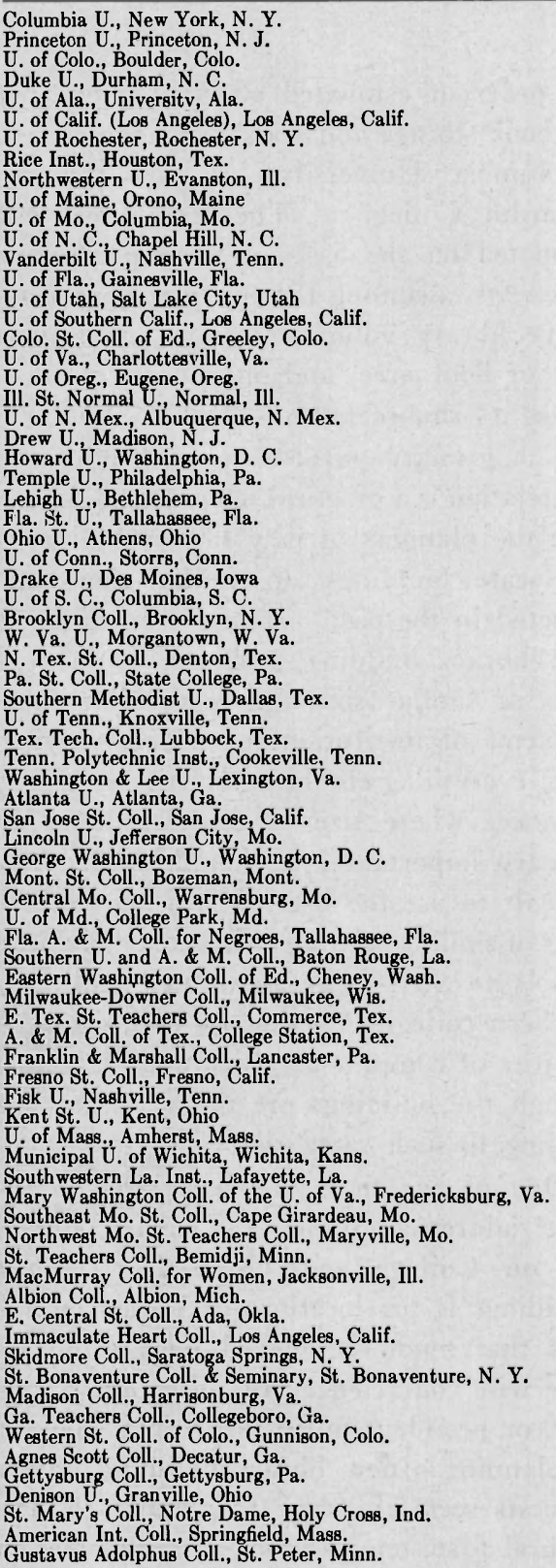 & 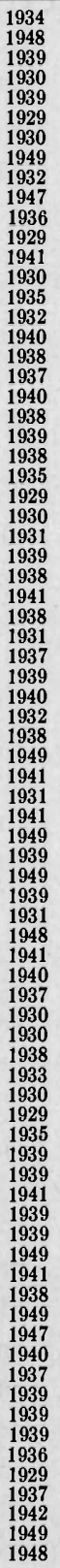 & 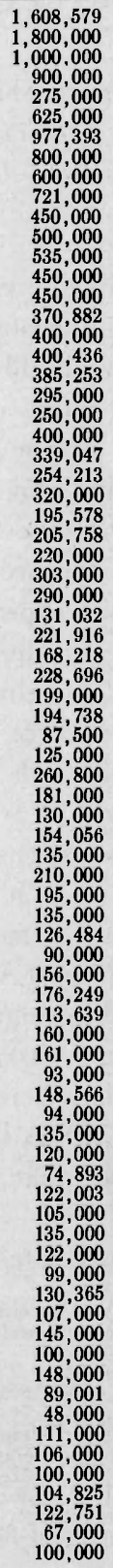 & $\begin{array}{l}x \\
x \\
x \\
x \\
x \\
x \\
x \\
x \\
x \\
x \\
x \\
x \\
x \\
x \\
x \\
x \\
x\end{array}$ & 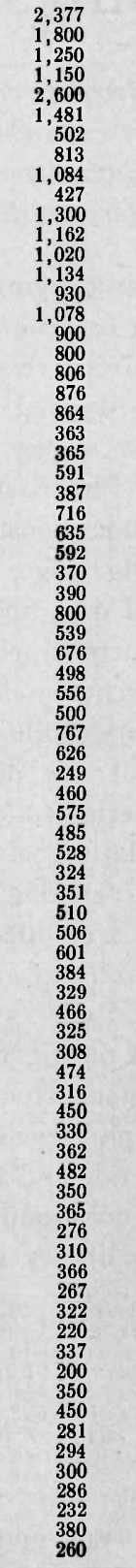 & 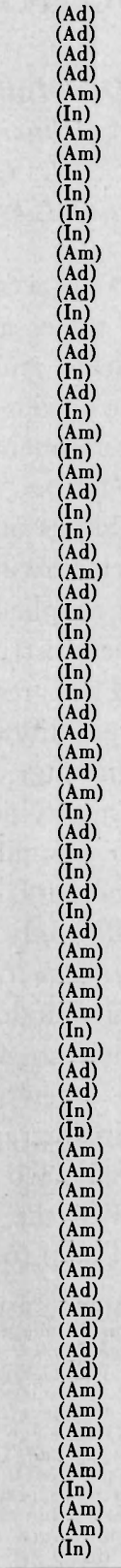 & , \\
\hline
\end{tabular}




\begin{tabular}{|c|c|c|c|c|c|}
\hline Name of Institution & $\begin{array}{l}\text { Year } \\
\text { Built }\end{array}$ & $\begin{array}{c}\text { Total } \\
\text { Volume } \\
\text { Capacity }\end{array}$ & $\begin{array}{c}\text { Building } \\
\text { now } \\
\text { Filled } \\
\text { (x for yes) }\end{array}$ & $\begin{array}{l}\text { Seats } \\
\text { plus Carrells } \\
\text { in Main } \\
\text { Library }\end{array}$ & \begin{tabular}{l}
\multicolumn{2}{c}{ Seats } \\
Adequate $(\mathrm{Ad})$ \\
Ample $(\mathrm{Am})$ \\
Insufficient $(\mathrm{In})$
\end{tabular} \\
\hline 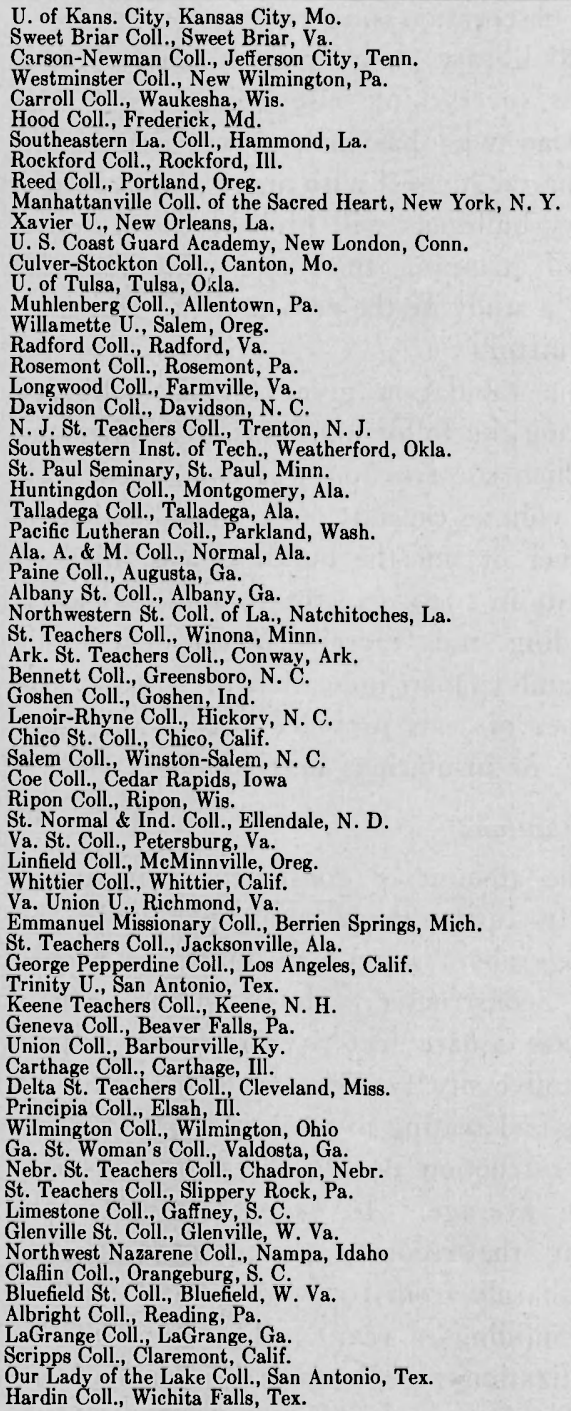 & $\begin{array}{l}1936 \\
1929 \\
1949 \\
1938 \\
1942 \\
1941 \\
1940 \\
1940 \\
1929 \\
1942 \\
1937 \\
1943 \\
1949 \\
1930 \\
1930 \\
1938 \\
1931 \\
1936 \\
1939 \\
1941 \\
1930 \\
1929 \\
1949 \\
1930 \\
1939 \\
1948 \\
1948 \\
1947 \\
1935 \\
1936 \\
1939 \\
1930 \\
1939 \\
1940 \\
1942 \\
1933 \\
1938 \\
1931 \\
1930 \\
1931 \\
1938 \\
1935 \\
1929 \\
1948 \\
1937 \\
1939 \\
1940 \\
1946 \\
1929 \\
1931 \\
1941 \\
1941 \\
1939 \\
1935 \\
1942 \\
1940 \\
1929 \\
1939 \\
1941 \\
1931 \\
1944 \\
1948 \\
1938 \\
1930 \\
1949 \\
1931 \\
1947 \\
1946\end{array}$ & $\begin{array}{r}125,000 \\
81,603 \\
100,000 \\
112,934 \\
87,512 \\
38,270 \\
90,702 \\
90,000 \\
90,000 \\
96,122 \\
79,000 \\
131,300 \\
100,000 \\
65,000 \\
130,000 \\
65,000 \\
101,000 \\
89,000 \\
51,566 \\
75,000 \\
75,000 \\
90,000 \\
103,000 \\
75,000 \\
41,000 \\
70,000 \\
58,000 \\
69,753 \\
15,000 \\
53,946 \\
58,500 \\
34,000 \\
68,411 \\
42,000 \\
74,892 \\
54,000 \\
53,791 \\
55,000 \\
58,000 \\
70,618 \\
43,799 \\
39,492 \\
64,230 \\
30,457 \\
40,000 \\
21,798 \\
32,000 \\
44,900 \\
41,050 \\
38,000 \\
19,350 \\
35,000 \\
45,060 \\
42,000 \\
40,000 \\
24,539 \\
31,500 \\
32,000 \\
30,000 \\
30,000 \\
25,000 \\
14,075 \\
15,000 \\
25,000 \\
14,680 \\
35,000 \\
13,000\end{array}$ & $\begin{array}{l}\mathbf{x} \\
\mathbf{x} \\
\mathbf{x} \\
\mathbf{x} \\
\mathbf{x} \\
\mathbf{x} \\
\mathbf{x} \\
\mathbf{x} \\
\mathbf{x} \\
\mathbf{x} \\
\mathbf{x} \\
\mathbf{x} \\
\mathbf{x} \\
\mathbf{x} \\
\mathbf{x}\end{array}$ & $\begin{array}{r}185 \\
300 \\
244 \\
209 \\
260 \\
387 \\
238 \\
228 \\
225 \\
202 \\
244 \\
100 \\
177 \\
270 \\
96 \\
263 \\
160 \\
190 \\
284 \\
218 \\
216 \\
172 \\
137 \\
204 \\
294 \\
214 \\
236 \\
196 \\
96 \\
225 \\
185 \\
242 \\
150 \\
220 \\
130 \\
170 \\
156 \\
152 \\
140 \\
105 \\
170 \\
180 \\
110 \\
200 \\
174 \\
216 \\
188 \\
150 \\
150 \\
158 \\
202 \\
158 \\
120 \\
125 \\
108 \\
124 \\
120 \\
120 \\
\end{array}$ & 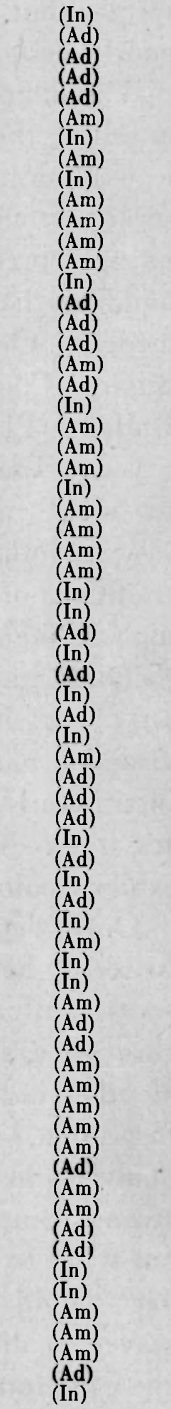 \\
\hline
\end{tabular}

the complex and often controversial body of knowledge pertaining to modern library building design and construction. The lists of recent and future library buildings were compiled to meet this demand for easy firsthand orientation more efficiently than could be done in the past.

Although the desire to seek firsthand knowledge about other library buildings seems legitimate, a word of caution is in order with regard to the tendency of some administrators to copy the plans of other buildings. Many examples could be cited of library buildings modeled after other library buildings with insufficient regard for the special conditions existing on a 
given campus. In some few cases the following of a model has produced functional results, but more often it has resulted in poorly designed library buildings.

The difficulties encountered by librarians in selling the idea of modular design to college administrators and boards up to 1946 sprang from the impossibility of pointing to any previously built modular library building that could be copied or used as a model. ${ }^{4}$ Only after some members of the original Cooperative Committee on Library Building Plans, such as Princeton University and Iowa State University, had begun to adopt modular design, did it become easy for others to break with the hallowed traditions of segregated multiple-tier stacks, high-ceilinged reference halls, built-in wall shelving and load-bearing partitions. ${ }^{5}$ In I95 I the situation is approaching the reverse of that of only five years ago, and institutions not adopting modular design for their library building seem now to exhibit apologetic tendencies.

Once the library planner is determined to resist the tendency to copy existing patterns unthinkingly, he can profit much through a study of library building plans of other institutions. By means of personal inspection, correspondence, discussion and analysis, he can discover the weak and strong points of other plans. He can find out what to avoid and what to recommend. He should insist on being permitted to travel to distant points if necessary, since. the most functional buildings are not always located nearby. The cost of such travel is

4 The application of flexible design to library build. ings was first proposed by Angus S. Macdonald. See his "A Library of the Future." Library Journal, 58:971-75, 1023-25, 1933 and "New Possibilities in Library "Planning." Library Journal, 70:1169-74, 1945. See also Burchard, John E., [and others]. Planning the University Library Building. Princeton

University Press, I 949, p.98-106, 1 36-37. Plans. The Orange Conference, Oct. 26.28, 1945, PhilaPlans. The Orange Conference, Oct. 26-28, 1945 , Phila-
delphia : Stephenson-Brothers, I946; See also The Second Princeton Conference, June 12-14, 1946, The North Carolina Conference, Mar. 18-19, 1947, The Chicago Conference, Jan. $27 \cdot 28$, I948, The Michigan Conference, Dec. 2-3, I 949 . a trifle compared to the cost of construction or compared to architects' fees. Firsthand observation is, of course, not a panacea for all library planning problems. Nevertheless, everything else being equal, the librarian who has had an opportunity to familiarize himself with many contemporary library buildings will probably do a better job of planning than one who has not. Even a study of the errors of the past may be fruitful.

The tabulation gives for each library building the following data: ( I) The year in which construction was completed, (2) total volume capacity, (3) an indication of whether or not the building was filled to capacity in $1949,(4)$ total number of seats, including study carrells, in the new building, and (5) an indication of whether the number of seats provided was ample, adequate, or insufficient in 1949.

\section{Fluctuations ${ }^{6}$}

The amount of construction fluctuated greatly during the 2 I-year span. On the average about seven new buildings a year were constructed, thus adding about I 54,000 square feet a year to the college and university facilities for the storage of books and seating of readers. The volume of construction during the depression was above average. It dropped considerably during the recovery period $1933-37$ and rose sharply from 1938 until Pearl Harbor ( 14 buildings a year). The war and demobilization periods were extremely lean, with only $\mathrm{r} .6$ buildings a year added. Library building construction picked up again in 1948 and 1949.

\section{Total Construction}

During 1929-49 new library buildings provided 3,300,000 square feet of floor area

\footnotetext{
6 Assistance rendered the author by Dr. A. Mark, director, Statistical Service, Southern Illinois University, in the calculation of the summary data, trends, and ratios presented in this and the next three paragraphs, is gratefully acknowledged.
} 
for the storage of $26,600,000$ books and $6 \mathrm{I}, 000$ seats for readers. In the total scene, for every Ioo square feet of floor area for book storage there were 85 square feet for reader seating. (This ratio did not, of course, hold true for individual libraries.) About I 4 per cent of the libraries accounted for one half of the total book storage capacity, and 22 per cent accounted for one half of reader seating, indicating that many more small libraries were constructed than large ones.

\section{Average Library}

The average building provided a book storage capacity of about i 84,000 volumes and seats for 420 readers. At the time of construction, it possessed about 6I,000 volumes. The library buildings of Atlanta University, A. \& M. College of Texas and Eastern Washington College of Education came close to this statistical average.

\section{Life Expectancy}

Of I 45 library buildings erected between 1929 and 1949,63 were filled to capacity by 1949. Over one half of the buildings built between 1929 and I94I were filled by 1949. On the basis of reported growth plus extrapolated future growth, among 122 buildings for which such data were available, the average library building had a life time or life expectancy of $2 \mathrm{I}$ years. ${ }^{7}$ In other words, the average building would require a building addition for book storage 2 I years after original construction.

\footnotetext{
T Life expectancy was computed on the basis of the average rate of increase for the period extending from the year of construction to the year 1948 . The rate of increase was computed in the same fashion as compound interest is computed. If $A$ denotes the number of volumes at the time of construction and $B$ the number of volumes in 1948 , then A dollars deposited in the year of construction would yield B dollars in 1948, provided that the money accumulated only through interest compounded annually at the rate of increase characteristic for a given library. The rate of increase was acteristic for a given library. The rate of increase was
calculated only for those libraries for which the numbers $A$ and $B$ were available.
}

\section{Circulation in the Divisional Library}

\section{(Continued from page 244)}

needed, that for the bookcard file kept by date due, from which overdues were typed and circulation counted. In these two last steps, needless minutes formerly spent on bookcarding, filing and writing charges, were saved for advising and guiding the patron.

\section{Summary}

At Nebraska the centralization of all circulation activities in the divisional library at the central loan desk has meant a new concept of service to the patron. The circulation department is in a pivotal position in the library; it is the center of public service and coordination. Through the use of a master file of book location and streamlined techniques of filing and book charging, this circulation department has elevated the standards of service to patrons to a high level of quality and efficiency, and has thus contributed substantially to the success of the divisional library at the University of Nebraska. 